\title{
Luteal function after ovulation blockade by intrafollicular injection of indomethacin in the ewe
}

\author{
W. J. Murdoch and T. G. Dunn \\ Division of Animal Science, University of Wyoming, Laramie, Wyoming 82071, U.S.A.
}

\begin{abstract}
Summary. The dominant follicle of oestrous ewes was injected with saline or indomethacin. Treated follicles were obtained at 2 and 10 days after treatment and examined histologically. Indomethacin-injected follicles were abnormally enlarged and remained unruptured. On Day 2 after treatment, these follicles appeared grossly hyperaemic. The follicular walls of control and indomethacin-treated groups had luteinized. Blood samples for the measurement of serum progesterone were collected from animals with their ovaries left intact. Systemic progesterone and oestrous cycle lengths were unaltered by drug administration. It appears that prostaglandins are essential for ovulation in the ewe. The occurrence of ovulation per se was not a prerequisite of ensuing luteal-phase normality.
\end{abstract}

\section{Introduction}

There is now overwhelming support for the concept that prostaglandins, synthesized within the preovulatory follicle in response to a gonadotrophic stimulus, are involved in the ovulatory mechanism of several mammalian species (Espey, 1980; Inskeep \& Murdoch, 1980; Armstrong, 1981). Much of the research in this area has been based on the use of inhibitors of synthesis of prostaglandins, particularly indomethacin. Although this drug was capable of preventing follicular rupture in rats (Armstrong \& Grinwich, 1972; Orczyk \& Behrman, 1972), rabbits (Grinwich, Kennedy \& Armstrong, 1972; O'Grady, Caldwell, Auletta \& Speroff, 1972), monkeys (Wallach, de la Cruz, Hunt, Wright \& Stevens, 1975) and pigs (Ainsworth et al., 1979), it apparently did not affect the transformation of follicular tissue into luteal tissue. Therefore, the mechanisms regulating ovulation and luteal development and function might be completely separable.

The objective of the succeeding experiment was to determine whether a small quantity of indomethacin injected directly into the antrum of the preovulatory follicle of the ewe would block ovulation without subsequently altering luteal endocrine activity or the duration of the luteal phase.

\section{Materials and Methods}

General. Western-range ewes were observed for oestrous behaviour with vasectomized rams at 12-h intervals. The first day of standing oestrus was considered Day 0 of the oestrous cycle (average length $\simeq 17$ days). 
At $12 \mathrm{~h}$ after the first detection of oestrus, ewes were anaesthetized by intravenous injection of thiopentone sodium and prepared for mid-ventral abdominal laparotomy. The reproductive tract was exteriorized and the ovary with the largest (preovulatory) follicle was identified; $20 \mu \mathrm{l}$ phosphate-buffered saline or $20 \mu \mathrm{l}$ phosphate-buffered saline containing a suspension of $100 \mu \mathrm{g}$ indomethacin (Sigma Chemical Co., St. Louis, MO, U.S.A.) were injected into the antrum of this follicle. Intrafollicular injections were made with a 100- $\mu$ l Hamilton syringe fitted with a 27 -gauge hypodermic needle. To avoid loss of follicular fluid through the site of puncture, the needle was inserted into the stroma of the ovary adjacent to the preovulatory follicle and the tip of the needle then directed into the follicular cavity. Since more than one follicle sometimes ovulates in the ewe, any large antral follicles (i.e. $>6 \mathrm{~mm}$ ), other than the largest follicle, were destroyed by electrocautery. This was done to limit the potential number of luteal structures per animal to one. The ovarian location of the dominant follicle was recorded. Based on previous observations indicating that the peak of the surge of luteinizing hormone (LH) consistently occurs during the first $12 \mathrm{~h}$ of oestrus (Niswender, Roche, Foster \& Midgley, 1968; W. J. Murdoch, unpublished data), it was assumed in this study that treatments were applied after the preovulatory peak in pituitary secretion of $\mathrm{LH}$.

Luteal morphology and ovarian venous concentrations of progesterone on Day 2 of the post-treatment oestrous cycle. Ewes (4/group) underwent a second laparotomy $48 \mathrm{~h}$ after treatment (animals normally ovulate by $24 \mathrm{~h}$ after the onset of the preovulatory surge of LH; Murdoch, Nix \& Dunn, 1983). Ovaries were inspected for an ovulation point and luteal tissue with respect to the preovulatory follicle noted at the time of first surgery. A blood sample was collected from the vein draining the ovary with the luteal structure and serum radioimmunoassayed for progesterone. The assay procedure and antiserum (No. 337) have been described (Niswender, 1973) and implemented for use in our laboratory (Moseley, Forrest, Kaltenbach \& Dunn, 1979). The sensitivity of the system was $0.0078 \mathrm{ng} /$ tube and intra- and inter-assay coefficients of variation were $<12 \%$. The ovarian structure of interest was isolated from surrounding tissues, fixed in $10 \%$ buffered formalin and processed for standard haematoxylin and eosin histology. Serial sections ( $8 \mu \mathrm{m}$ thickness) of these tissues were examined by light microscopy.

Systemic concentrations of progesterone throughout the post-treatment oestrous cycle. Eight ewes per group were treated as described above with the exception that ovaries were not removed on Day 2 ; from the day after the 2nd laparotomy (Day 3) until the expression of oestrus, blood samples were collected via jugular venepuncture at each twice daily heat check. Progesterone concentrations in the serum were measured as indicated above.

Effect of indomethacin on synthesis of prostaglandin within the periovulatory follicle. To confirm inhibition of prostaglandin (PG) synthetase activity by indomethacin, control and drug-treated follicles $(n=6)$ were removed at about the time when ovulation would normally be expected to occur ( $12 \mathrm{~h}$ after treatment), homogenized, extracted twice with $3 \mathrm{ml}$ ethyl acetate, and duplicate aliquots of each extract radioimmunoassayed for PGF- $2 \alpha$ using a kit (Clinical Assays Inc., Cambridge, MA, U.S.A.). Mean recovery of $\left[{ }^{3} \mathrm{H}\right] \mathrm{PGF}-2 \alpha$ from follicular homogenates $(n=8)$ was $76.4 \%$. The sensitivity of the assay was $9.9 \mathrm{pg} /$ tube. All samples were included in the same assay (intra-assay coefficient of variation $=8.6 \% ; n=8$ ) and the values subsequently corrected to reflect extraction loss. Parallelism existed between the inhibition curves obtained with standards and different dilutions of a pool of extracted tertiary follicles.

Luteal morphology and ovarian venous concentrations of progesterone on Day 10 of the posttreatment oestrous cycle. Ovarian venous blood samples for serum determinations of progesterone were collected ipsilateral to ovaries $(n=4)$ containing the treated follicle. Treated ovarian structures were prepared for microscopic inspection.

Statistics. Analysis of variance for a split-plot design (Gill \& Hafs, 1971) was used to evaluate differences between treatments in patterns of concentrations of peripheral sera progesterone. Student's $t$ test was used to examine for treatment differences in ovarian venous concentrations of serum progesterone, oestrous cycle lengths and follicular content of PGF- $2 \alpha$. 


\section{Results}

When ovaries with a treated follicle were observed $48 \mathrm{~h}$ after intrafollicular injections were made, two distinctly disparate outcomes were apparent: (1) an ovulation stigma was present on the surface of all control follicles, whereas (2) follicular rupture was effectively $(100 \%)$ prevented by indomethacin (Pl. 1, Figs $1 \& 2 ; n=12$ ). Indomethacin-treated follicles had clearly grown (accumulated fluid) to the point where they dominated the ovary (Pl. 1, Fig. 2). Blood vessels were often quite pronounced in the wall of these follicles.

Morphological luteinization of the wall of the control and drug-treated follicles was apparent from microscopic examination of tissues which were collected on Day 2. However, compared with control follicles, the tissue layer of indomethacin-treated follicles was distended (Pl. 1, Figs $3 \& 4$ ), and as observed superficially, blood vessels within the walls of these follicles appeared to be dilated and engorged; numerous blood cells were consistently found within the luteal tissue (PI. 1, Fig. 4) and follicular cavity. Cells of the cumulus pedicle and corona radiata of all the follicles injected with indomethacin had dispersed, leaving a degenerate oocyte floating within the follicular antrum. Ovarian venous concentrations of serum progesterone (mean \pm s.e.m.) were higher for ovaries containing luteinized unruptured follicles than for ovaries with ruptured follicles $(178 \pm 28$ compared with $112 \pm 23 \mathrm{ng} / \mathrm{ml}$, respectively; $P<0.05$ ).

Although ovulation was inhibited by indomethacin, the length of the post-treatment oestrous cycle was not altered: $17 \cdot 1 \pm 0 \cdot 4$ days in control ewes, $16 \cdot 9 \pm 0 \cdot 4$ in the indomethacin-treated ewes. Likewise, patterns of concentrations of progesterone in jugular venous sera throughout the luteal phase were similar for both groups (Text-fig. 1).

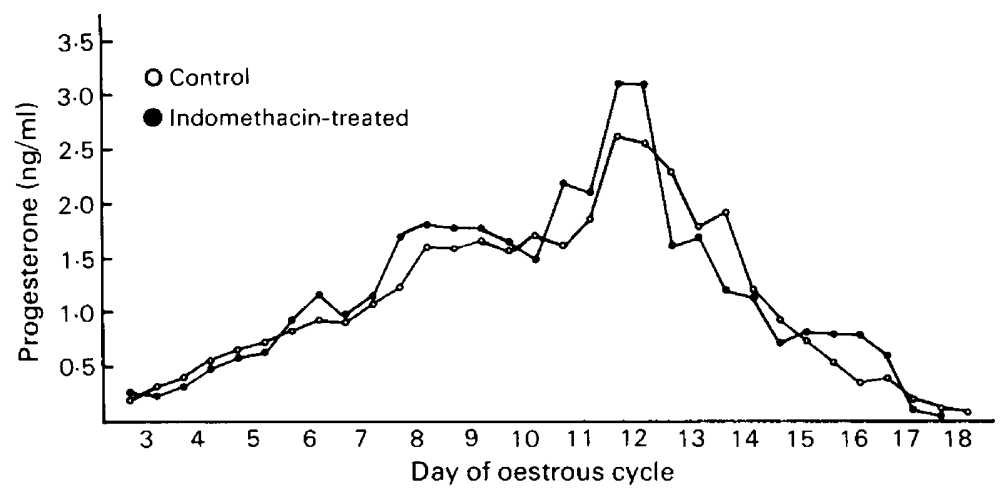

Text-fig. 1. Peripheral serum concentrations of progesterone during the luteal phase of control and indomethacin-treated animals.

At $12 \mathrm{~h}$ after treatment, 3 of 6 control follicles and 0 of 6 indomethacin-treated follicles had ruptured. Indomethacin markedly suppressed follicular content of PGF- $2 \alpha(1.8 \pm 0.6$ compared with $13.4 \pm 1.9 \mathrm{ng} /$ follicle; $P<0.01$ ).

Ovaries which contained an indomethacin-treated follicle were enlarged, possessed no ovulation papilla, and had a prominent antrum on Day 10 (Pl. 2, Figs $5 \&$ 6). Concentrations of progesterone in ovarian venous sera on Day 10 were not different for ovaries with control or indomethacin-treated follicles $(1.3 \pm 0.3$ and $1.5 \pm 0.4 \mu \mathrm{g} / \mathrm{ml}$, respectively); luteal tissues were indistinguishable from each other (Pl. 2, Figs $7 \& 8$ ). 


\section{Discussion}

Over one decade ago it was first demonstrated that indomethacin would block ovulation in rats (Armstrong \& Grinwich, 1972; Orczyk \& Behrman, 1972) and rabbits (Grinwich et al., 1972; O'Grady et al., 1972). At that time it was uncertain at what site (hypothalamus-pituitary or ovary) the drug was exerting its influence. It now seems evident that indomethacin acts at the ovarian (follicular) level (Armstrong, Grinwich, Moon \& Zamecnik, 1974; Hamada, Bronson, Wright \& Wallach, 1977). The present report extends to the ewe the observation that inhibition of follicular synthesis of prostaglandins by indomethacin is effective in preventing ovulation, and supports the contention that the drug has its effect within the preovulatory follicle (indomethacin was administered to the follicle directly, in a small amount, after the expected time of the preovulatory surge of $\mathrm{LH}$ ). The formation of luteal tissue in the ewe is apparently not prostaglandin-dependent. These findings are consistent with the feeling that the prostaglandins are mediators of LH-directed ovulation, but not an obligatory component in the luteinizing action of LH (Phi, Moon \& Armstrong, 1977).

The macroscopic appearance of follicles that had been injected with indomethacin was striking and these structures could have been classed as luteinized cysts - the follicles were at least twice the size of normal ovulatory follicles, yet had failed to rupture. The vessels and tissue of these follicles were engorged with blood on Day 2, and, although indomethacin is generally thought of as an antiinflammatory drug, indomethacin-treated follicles were conspicuously inflamed. Murdoch et al. (1983) have reported that ovarian blood supply to the ovine follicle destined to ovulate increases during the time of the surge of $\mathrm{LH}$ and is followed by a precipitous decline in blood supply as the time of follicular rupture approaches. Since follicular tissue PGE-2 (a vasodilator) concentration is known to be low and PGF-2 $\alpha$ (a vasoconstrictor) to be elevated at the time of follicular rupture (Murdoch, Dailey \& Inskeep, 1981), it was speculated (Murdoch et al., 1983) that the fall in follicular blood supply was mediated by PGF- $2 \alpha$, and that a resultant condition of tissue ischaemia could be an important component of the ovulatory scheme.

The reason for the elevated serum concentrations of progesterone in the vein of ovaries with indomethacin-treated follicles during the very early luteal phase is unclear. Increased follicular blood flow could be used to argue for an augmented opportunity for progesterone to gain entry to the vascular system. In any case, concentrations of progesterone in ovarian venous serum on Day 10 and in peripheral sera throughout the oestrous cycle were not different for indomethacin and control groups. Moreover, it seems that the factors that controlled the life of luteinized unruptured follicles were similar to those which influenced normal (ovulated) corpora lutea.

At first glance drugs such as indomethacin appear to have considerable potential for use in terms of fertility regulation (induction of infertile, normal-length cycles) in man. However, since this drug can produce undesirable peripheral side-effects (headache, gastrointestinal upset, blood dyscrasias, peptic ulcer) its usefulness as a systemically administered contraceptive would be

\section{PLATE 1}

Fig. 1. Ovary of a ewe containing a follicle that was injected with phosphate-buffered saline. $\mathrm{RF}=$ ruptured follicle. OS = ovulation stigma. Day 2 .

Fig. 2. Ovary with a follicle that was treated with indomethacin. Such follicles ranged from 13 to $20 \mathrm{~mm}$ in diameter. Follicles about to ovulate in the ewe are approximately $8 \mathrm{~mm}$ in diameter. UF = unruptured follicle. Day 2.

Fig. 3. Cross-sectional view of a portion of the wall of a control follicle. $A=$ antrum. Day 2. $\times 100$.

Fig. 4. Cross-sectional view of a portion of the wall of an indomethacin-treated follicle. $A=$ antrum. LG = luteinized granulosa. $\mathrm{RBCs}=$ red blood cells. $\mathrm{BV}=$ blood vessel containing RBCs. Day 2. $\times 200$. 
PLATF 1
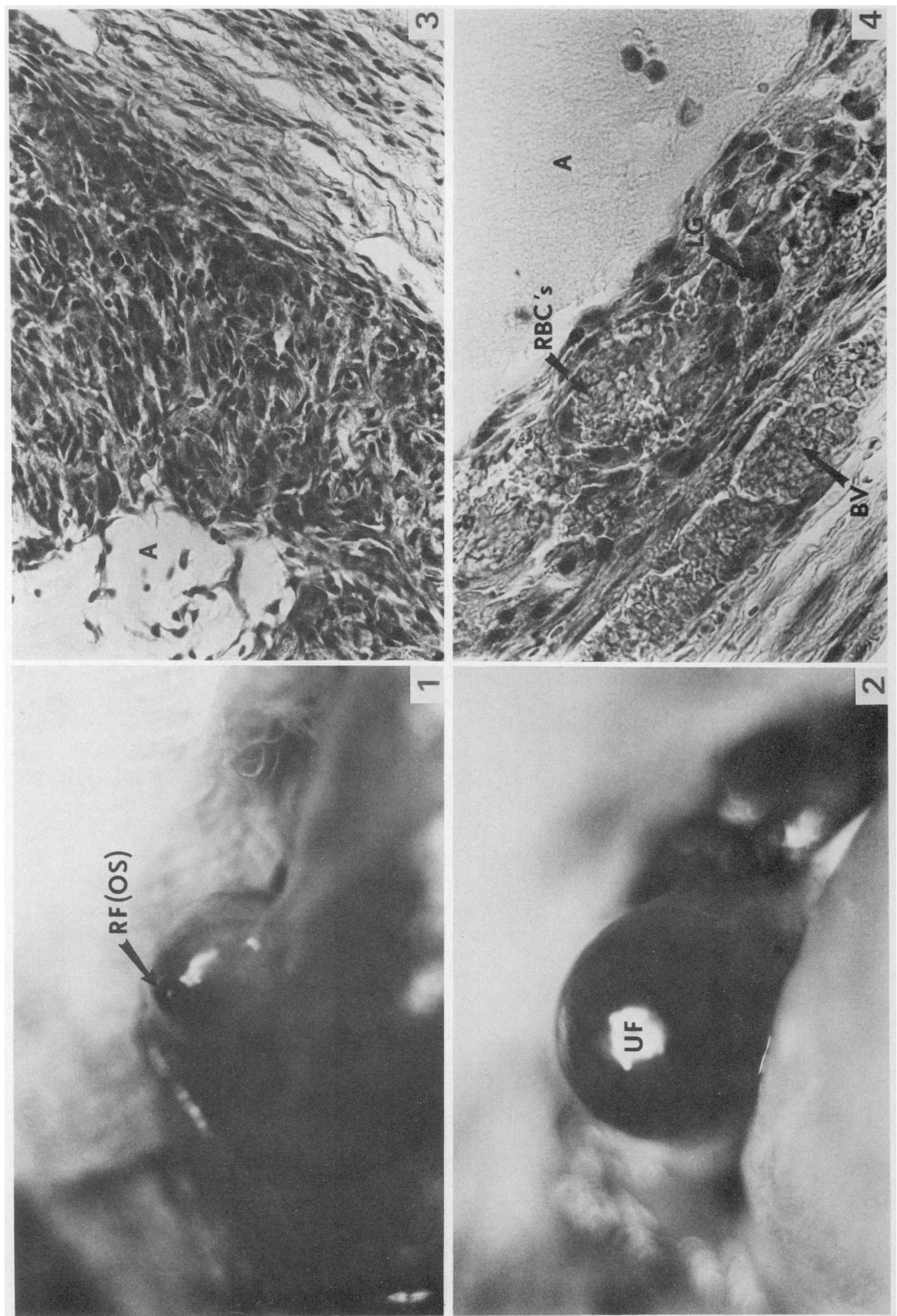


\section{PLATE 2}

3. $\%$ (a)

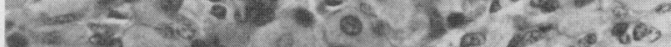

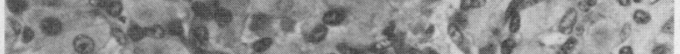

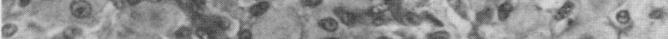

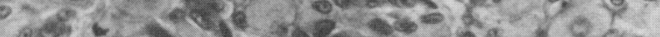

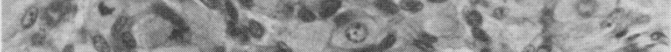

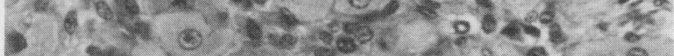

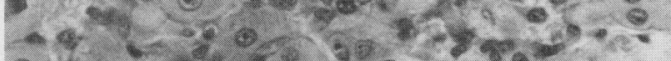

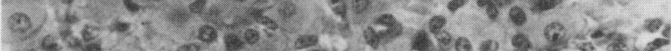

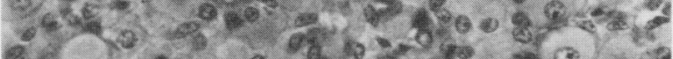

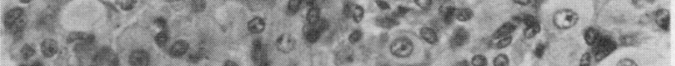

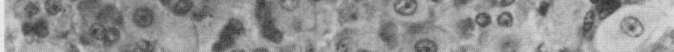

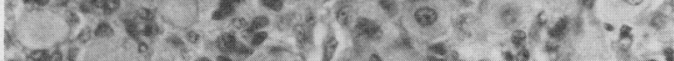

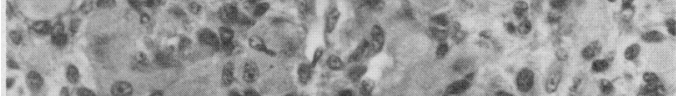

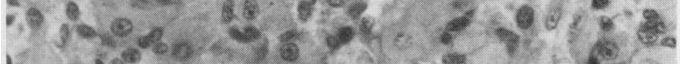

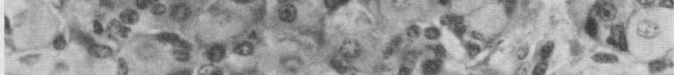

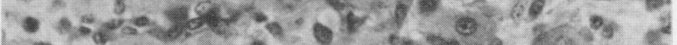

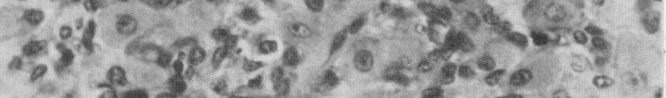

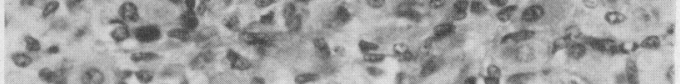

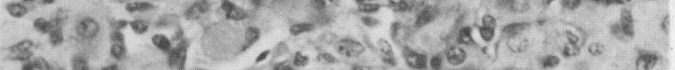

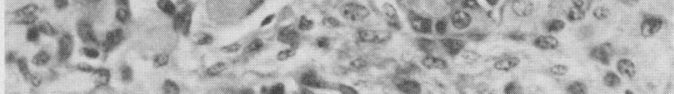

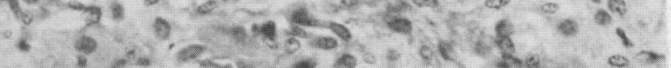

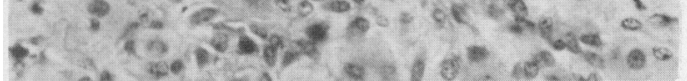

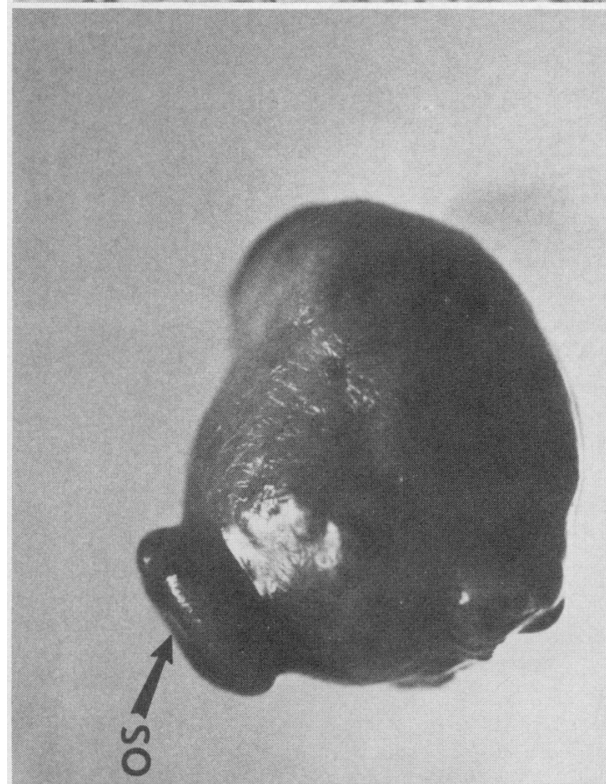

ת

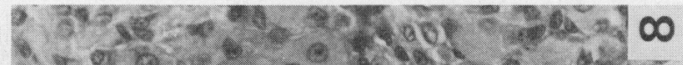

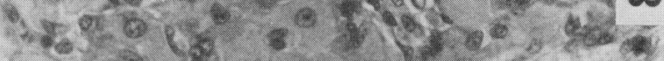

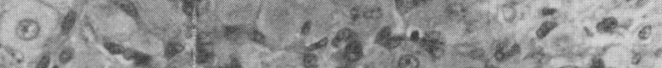

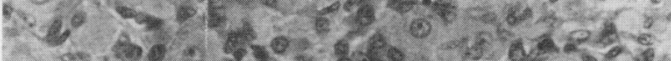
ct.

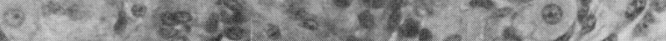

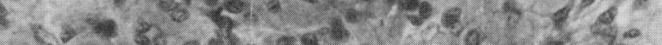
(1) 0 (a)

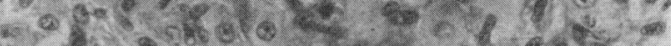
-

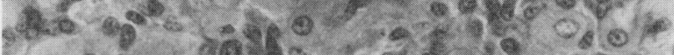

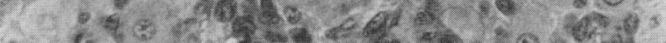

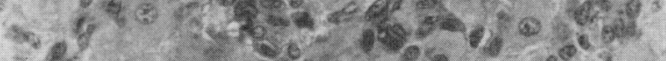
ales.

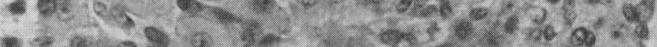

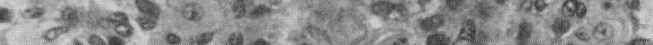
2.

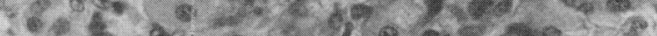

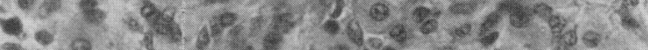

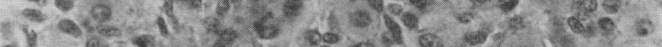

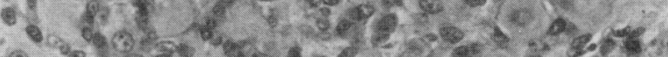
की

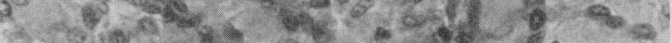

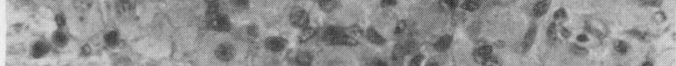

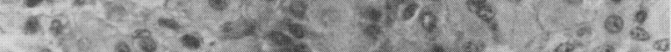

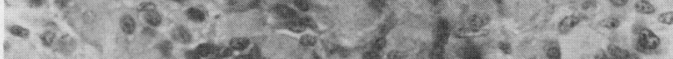

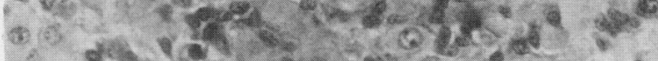

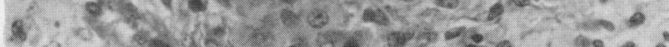

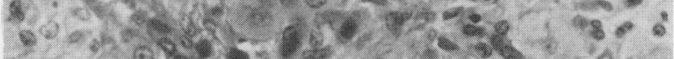

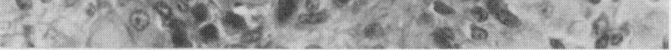

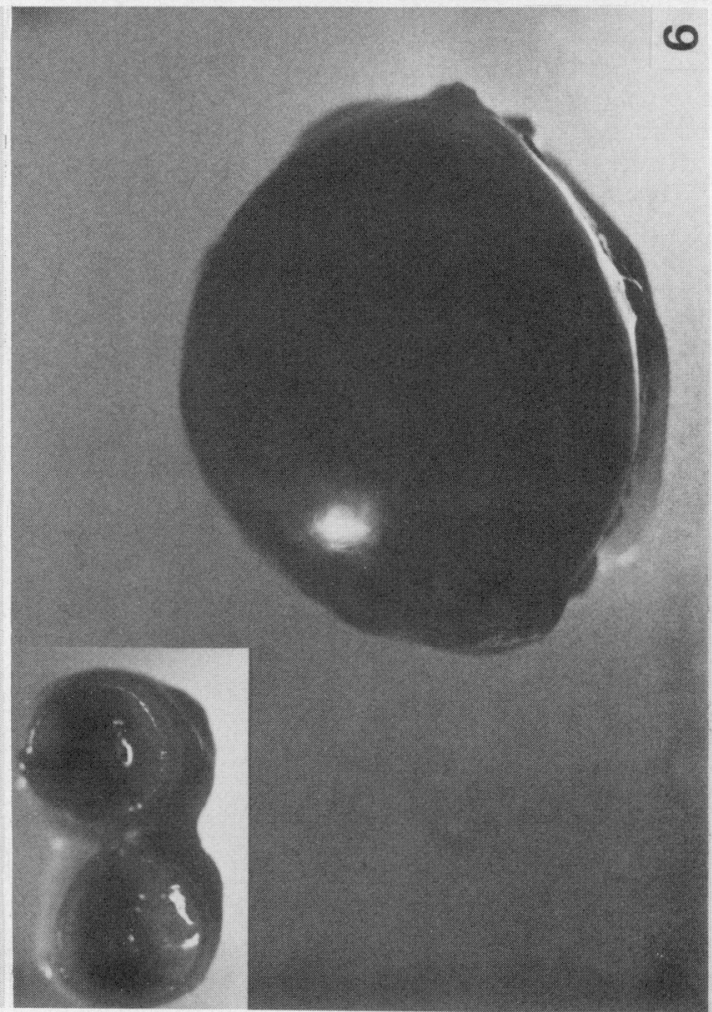


limited. If a drug that would inhibit the follicular synthesis or ovulatory action of prostaglandins could be delivered to the ovary via a local mechanism, a problem such as the one described above might be circumvented. An intrauterine delivery system may be a possible approach, especially since a direct vascular relationship exists between the uterus and ovaries of a number of species (Ginther, 1974), including man (Bendz, Einer-Jensen, Lundgren \& Janson, 1979).

\section{References}

Ainsworth, L., Tsang, B.K., Downey, B.R., Baker, R.D., Marcus, G.J. \& Armstrong, D.T. (1979) Effects of indomethacin on ovulation and luteal function in gilts. Biol. Reprod. 21, 401-411.

Armstrong, D.T. (1981) Prostaglandins and follicular functions. J. Reprod. Fert. 62, 283-291.

Armstrong, D.T. \& Grinwich, D.L. (1972) Blockade of spontaneous and LH-induced ovulation in rats by indomethacin, an inhibitor of prostaglandin biosynthesis. Prostaglandins 1, 21-36.

Armstrong, D.T., Grinwich, D.L., Moon, Y.S. \& Zamecnik, J. (1974) Inhibition of ovulation in rabbits by intrafollicular injection of indomethacin and prostaglandin F antiserum. Life Sci. 14, 129-140.

Bendz, A., Einer-Jensen, N., Lundgren, O. \& Janson, P.O. (1979) Exchange of krypton-85 between the blood vessels of the human uterine adnexa. J. Reprod. Fert. 57, 137-142.

Espey, L.L. (1980) Ovulation as an inflammatory reaction-a hypothesis. Biol. Reprod. 22, 73-106.

Gill, J.L. \& Hafs, H.D. (1971) Analysis of repeated measurements of animals. J. Anim. Sci. 33, 331-336.

Ginther, O.J. (1974) Internal regulation of physiological processes through venoarterial pathways: a review. J. Anim. Sci. 39, 550-564.

Grinwich, D.L., Kennedy, T.G. \& Armstrong, D.T. (1972) Dissociation of ovulatory and steroidogenic actions of luteinizing hormone in rabbits with indomethacin, an inhibitor of prostaglandin biosynthesis. Prostaglandins 1, 89-96.

Hamada, Y., Bronson, R.A., Wright, K.H. \& Wallach, E.E. (1977) Ovulation in the perfused rabbit ovary: the influence of prostaglandins and prostaglandin inhibitors. Biol. Reprod. 17, 58-63.

Inskeep, E.K. \& Murdoch, W.J. (1980) Relation of ovarian functions to uterine and ovarian secretion of prostaglandins during the estrous cycle and early pregnancy in the ewe and cow. Int. Rev. Physiol. 22, 325-356.
Moseley, W.M., Forrest, D.W., Kaltenbach, C.C. \& Dunn, T.G. (1979) Effect of norgestomet on peripheral levels of progesterone and estradiol-17 $\beta$ in beef cows. Theriogenology 11, 331-341.

Murdoch, W.J., Dailey, R.A. \& Inskeep, E.K. (1981) Preovulatory changes in prostaglandins $E_{2}$ and $F_{2} \alpha$ in ovine follicles. J. Anim. Sci. 53, 192-205.

Murdoch, W.J., Nix, K.J. \& Dunn, T.G. (1983) Dynamics of ovarian blood supply to periovulatory follicles of the ewe. Biol. Reprod. 28, 1001-1006.

Niswender, G.D. (1973) Influence of the site of conjugation on the specificity of antibodies to progesterone. Steroids 22, 413-423.

Niswender, G.D., Roche, J.F., Foster, D.L. \& Midgley, A.R., Jr (1968) Radioimmunoassay of serum levels of luteinizing hormone during the cycle and early pregnancy in ewes. Proc. Soc. exp. Biol. Med. 129, $901-904$.

O'Grady, J.P., Caldwell, B.V., Auletta, F.J. \& Speroff, L. (1972) The effects of an inhibitor of prostaglandin synthesis (indomethacin) on ovulation, pregnancy, and pseudopregnancy in the rabbit. Prostaglandins 1, 97-106.

Orczyk, G.P. \& Behrman, H.R. (1972) Ovulation blockade by aspirin or indomethacin - in vivo evidence for a role of prostaglandin in gonadotropin secretion. Prostaglandins 1, 3-20.

Phi, L.T., Moon, Y.S. \& Armstrong, D.T. (1977) Effects of systemic and intrafollicular injections of $\mathbf{L H}$, prostaglandins and indomethacin on the luteinization of rabbit Graafian follicles. Prostaglandins 13, 543-552.

Wallach, E.E., de la Cruz, A., Hunt, J., Wright, K.H. \& Stevens, V.C. (1975) The effect of indomethacin on HMG-HCG induced ovulation in the rhesus monkey. Prostaglandins 9, 645-658.

Received 11 April 1983

\section{PLATE 2}

Fig. 5. Ovary containing a corpus luteum derived from a follicle that was injected with phosphate-buffered saline. OS = ovulation stigma. Day 10 .

Fig. 6. Ovary with a luteinized follicle resulting from treatment with indomethacin. Day 10.

Fig. 7. Photomicrograph of a section from a corpus luteum. Day 10. $\times 200$.

Fig. 8. Photomicrograph of a section of the wall of a luteinized follicle. Day 10. $\times 200$. 